\title{
Women Shellfish Collectors: Economic and Social Implications of the Shellfish Extractivism Perna perna (Linnaeus) in Paraná Coast, Brazil
}

\author{
Adilson Anacleto ${ }^{1}$, Alcione Mariano Pires de Oliveira ${ }^{1}$, Ana Paula Maia ${ }^{1}$, Karen Alice de Castro Rodrigues ${ }^{1} \&$ Thais \\ Mendes Da Silva ${ }^{1}$ \\ ${ }^{1}$ Paranaguá Campus, State University of Paraná, Paraná, Brazil \\ Correspondence: Adilson Anacleto, Paranaguá Campus, State University of Paraná, Paraná, Brazil.
}

Received: February 18, 2021

Accepted: April 1, 2021

Online Published: June 1, 2021

doi:10.5430/ijba.v12n4p34

URL: https://doi.org/10.5430/ijba.v12n4p34

\begin{abstract}
This study aimed to elaborate a diagnosis of the situation experienced by women who practice the collection of shellfish from Paraná Coast, revealing the economic and social implications of shellfish collection that may be limiting the activity. The study showed that women are predominant in the activity, and they are developing the activities related to the extraction of mollusks since adolescence. The study also revealed that women shellfish collector had an average of 4 children and had a low level of education and high levels of illiteracy. The average income obtained was on average of USD 107.90, with the majority of the interviewees ( $\mathrm{n}=93 \%)$ having in the activity the only source of income. It should be noted in relation to the income obtained, these women can be classified in the group of people living on the "poverty line" who are the people who receive an income of up to US\$ 5.5 (approximately R $\$ 22.00$ ) per day. $86 \%$ of the interviewees reported that, due to the humidity in the workplace and the repetitive movements, they already had some health problem. The main implications of the activity were associated to the low income measured with the activity and the unhealthy environment, and the potentialities such as income generation and the possibility of reconciling professional activities with domestic ones were the most positively highlighted. The collective organization can be considered the main alternative of this group of women in the fight for better remuneration, work environment and quality of life.
\end{abstract}

Keywords: artisanal fishing, Paraná Coast, fishing communities, shellfish

\section{Introduction}

Paraná began its coastal colonization in 1675, with new population to occupy the lands belonging to the Portuguese Crown. In this period, Paranaguá was founded and later the city of Antonina (Mafra, 1952). During the colonization process, in addition to the economic activities of extracting yerba mate and agriculture (Souza \& Silveira, 2016), the sea was considered to be the main source of food for the families by fishing in the artisanal system (Mafra, 1952). Fishing developed in an artisanal way is a prehistoric craft, one of the main means of obtaining food and human survival (Monteiro, 2014).

Even nowadays it is possible to find artisanal fishing practiced in a similar way to the colonization period in Paraná Coast, with rudimentary techniques, tools and boats in most cases, and the extraction of marine species being the main source of economic income for hundreds of people and families in the coastal communities (Andreoli \& Anacleto, 2006).

Artisanal fishing has many subdivisions, such as the capture of fish in the open sea, in bays and rivers, and in particular the collection of shellfish, seafood of great acceptance as food nowadays and a delicacy classified as very tasty (Anacleto, Cordeiro, Mattos \& Elero, 2010).

Among the people involved in the commercial extraction of seafood, women shellfish collectors stand out, women who work in all stages of the shellfish production chain. They operate almost entirely in the processes of cleaning and processing, being estimated that $99 \%$ of this process is carried out by women classified as shellfish gatherers (Anacleto et al., 2010). This group of women is also called artisanal fisherwomen (Pena, Freitas \& Cardim 2011).

This activity is configured in several stages, such as the collection of shellfish on the beach, in the sea, mangrove or river and the processing of production, which ranges from boiling the mollusk, packaging and then the product commercialization. (Falcão et al., 2015). 
The Paraná Coast has a wide variety of typical dishes and in many of them seafood, shellfishes or mussels are complemented by the delicacy, such as cambira (dried fish stock cooked with tomatoes, peppers, coriander, pepper and bananas), rice lambe-lambe, (type of risotto with mussels with the shells) and caldeirada, a kind of stew with several kind of seafood. These delicacies are prepared and consumed by local families and also served with great acceptance in restaurants during summer time (Anacleto et al., 2010).

The shellfishes or mussels are marine mollusks belonging to the family of Mytilidae. The bivalve mollusk Perna perna is the largest and most abundant Mytilidae in Brazilian Coast. It has great socioeconomic importance, which in addition to providing food for human consumption, being a low-cost protein source, still generates income for hundreds of families in vulnerable conditions in Paraná Coast (Simon \& Silva, 2006; Anacleto et al., 2010).

Paraná Coast has shown a decline in the fishing activity, especially due to overfishing that has been imposing a new reality to the communities, where the activity no longer supplants the families' condition of survival. The overexploitation of marine resources is due to the intense population increase, accompanied by the fast improvement of the capture technologies, by improper legislation, lack of inspection and disorganization of the fishing sector, and this situation being more noticeable in the summer time, when a higher population, usually ten times more than the resident one, moves to that region, consuming large quantities of seafood. Overexploitation is seen as very worrying, given the availability of shellfish in natural environments that has been drastically reduced in the last decade, and studies evaluating the management models adopted in the processes of catching and trading of this kind of seafood are sparse.

In the urgent need for diagnoses on management models in the exploitation of seafood, such as the shellfish case, Castello (2007) warns that the rapid expansion of fishing has led to a $30 \%$ decline in the abundance of fish in the North Sea in the last decade of the 19th century, and that there is still the idea that marine resources are inexhaustible, and he highlights that the diagnosis on fishing activities can in fact guide the correct sustainable management of fishing resources. Despite the important role played by women in the fishing sector, the social space that they occupy has remained invisible to the most researchers in the sector, as well as in particular they are not perceived mainly by the public authorities, although the close relationship with the environment and the extraction obtaining most or all of their family livelihood from the shellfish.

Thus, in such a scenario with scarcity of information on this economic activity, this study aimed to elaborate a diagnosis of the situation experienced by women shellfish collectors from Paraná Coast, showing the economic and social implications of extractivism and which may be limiting the activity.

\section{Material Studied}

Fishing according to Santos (2019) is a relevant economic activity in the world. It involves many people, both at sea and on land. Related activities are storage, how to distribute the seafood, incentive to the shipping industry, production of utensils and tools for fishing. The classifications of fishing activities are professional fishing, commercial fishing and artisanal fishing (Santos, 2019).

Artisanal fishing is a very old activity carried out as a way of subsistence. Men were determined to practice fishing at sea and women were related to cleaning and processing fish, in addition to other usual domestic tasks (Monteiro, 2014).

Artisanal fishing presents the subdivision of shellfish collection, which according to Figueiredo and Prost (2011) is an activity in which women predominate and the production is connected especially downstream (low tide). As the sea water goes down, the most favorable places for the collection of shellfish are exposed (Oliveira, Araújo, Steuer \& El-Deir, 2012), such as mangroves, estuaries and outcrops, facilitating the collection.

The collection of shellfish grew in relevance, since it became a source of income at low costs, causing the reduction of poverty in coastal communities, especially the poorest ones, where women took a leading role in the execution of this activity (Oliveira et al., 2012).

According to Cardoso (2002), the work carried out by women in fishing activity is generally not valued, given that in addition to activities related to fishing, a significant portion of women are providers of their homes, and still develop domestic activities (Figueiredo \& Prost, 2011), a behavior resulting from the tradition of fishermen that privileges the patriarchy (Cardoso, 2002). The conception of tradition according to Coutinho (2005) would be a cultural legacy and its reproduction through the idea of transmitting knowledge, practices and values from generation to generation, orally or through habit, and this is a factor observed in fishing communities in relation to shellfish collectors.

Shellfish collection is a widespread tradition in coastal cities in Brazil, as a means of human subsistence (Monteiro, 
2014). For this reason, Santos (2019) highlights the interdependence between the context in which the activity is inserted, communities that are more distant from urban and socially vulnerable centers. Aragão and Melo (2011) highlight that tradition occurs in the sense of solidifying the belonging to a place, reinforcing links with the environment and the sense of sharing with others. Alexandrino and Silva (2015) adds that traditions are strengthened through symbolic rites and practices, which are identified by the choice and constitution of certain values and norms of repetition and behavior (Santos, 2019). Little (2002) concludes and corroborate with that was described by Aragão and Melo (2011) in which, as well as the sense of belonging to a place, in the tradition there must also be the search for cultural autonomy and sustainable practices. A path to be envisioned by women shellfish collectors.

Although tradition does not treat women shellfish collector on an equal basis with fishermen, the activity still shows identity and economic importance (Monteiro, 2014; Santos, 2019). Since, according to Figueiredo and Prost (2011), the income obtained by them promotes that these women fulfill the role of transmitters the work and tradition, thus, they watch over the culture in the community from generation to generation.

The maintenance of culture occurs as these women start their activity in childhood (Figueiredo \& Prost, 2011) and according to Bourdieu, Curto, Domingos and Jerónimo. (1989), it is in this phase that this learning is accomplished, being divided among the house, the street, the sea and the school. Being born and growing in fishing communities enables practical learning and the development of skills related to shellfish collection, such as making fishing tools, identifying the best locations for capture, recognizing whether the weather is conducive to being at the sea and observing if the shellfish is in time to be collected (Fernandes, Lima \&Araújo, 2014).

Andreoli and Anacleto (2006) corroborate this by reaffirming that this professional area, as a profession, requires a wide domain of knowledge about the environment, built based on empirical data. In addition, in a general aspect, fishermen throughout their career experience, contrast and update knowledge in this environment, which will serve to confirm or modify some beliefs, enabling continuous learning and sharing of their technologies.

Shellfish collection is considered a health risk activity, given that women often work under strong humidity conditions, adverse situations to the maintenance of health and safety, as well as the degree of exposure to risks. Among them: physical, chemical and biological from the work environment. Added to this are the nature of the activity developed, the organizational characteristics and the existing interpersonal relationships (Ministério da Saúde [MS], 2018). Fishing in general has already presented around 60 occupational diseases, the most common of which are RSI - Repetitive Strain Injuries, skin cancer and decompression sickness (MS, 2018).

Despite the difficulties observed in the activity, shellfish collection continues to be practiced Paraná Coast, especially in traditional fishing communities, due to the knowledge built by its members individually or collectively over time. These communities were characterized by their own social system, adopted by successive generations. Another important characteristic of these communities is the preservation of the culture of the use of sea resources for family survival (Diegues, 1983).

\section{Method}

The survey-type methodology was carried out in a descriptive exploratory research. As for the nature, the research is quantitative and qualitative due to the use of data collection based on the self-perception of the interviewed, without worrying about the use of statistical techniques.

The study was carried out between March and December of 2020, it aimed to organize a current diagnosis about the situation experienced by 21 women shellfish collectors in Paraná Coast, diagnosing the economic and social implications of the activity.

\subsection{Characterization of the Study Region}

Paraná Coast is considered the third marine place for breeding aquatic animals in Brazil. It has 90 kilometers of Coast and with the sum of the bays of Guaraqueçaba, Antonina, Paranaguá and Guaratuba, it forms more than 400 kilometers of internal coast, representing a estuarine water mirror of considerable proportions (Simon \& Silva, 2006).

\subsection{Choice of Research Location}

The decline of fishing activity in Paraná Coast, due to predatory fishing, according to Anacleto et al. (2010), has been imposing a new reality to the traditional communities, where the economy no longer surpasses the condition of the activity survival, causing an exodus of families to other regions, the mass abandonment of the fishing activity or the transfer of activity to more promising ones, as in the case of the shellfish production, that increases the possibilities to improve the community economy. It is noteworthy that this economic activity in Paraná Coast, is 
strongly associated with low-income communities, being this the main factor in choosing the research location. And, also according to Anacleto et al., (2010) the municipality of Antonina concentrates a large number of women shellfish collector, living in socially vulnerable communities where seasonal tourism has little influence on the development of the activity.

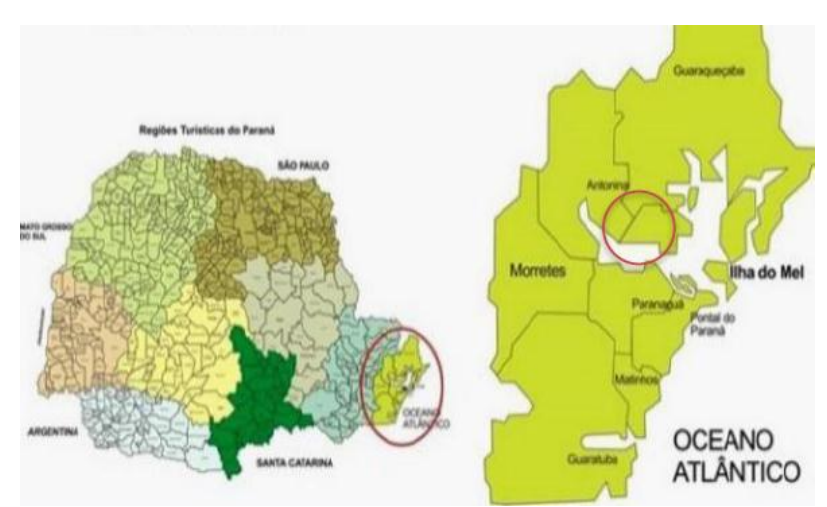

Figure 1. Geographic location of fishing communities with the largest number of women shellfish collectors in Antonina - Paraná

The communities are, on average, $10 \mathrm{~km}$ away from downtown area. The study site was also chosen because it is a fishing community with a long tradition of shellfish collection.

\subsection{The Visits Period, Data Collection and Analysis}

For data collection, it was used a semi-structured interview (Vergara, 2015) with a pre-elaborated question script. The interview was carried out in the places where these women lived who voluntarily agreed to participate in the research.

The field data collection was carried out maintaining the distance patterns in order to avoid contact between interviewees and researchers. In addition, the interview also adopted standards recommended by the competent authorities, such as wearing masks and controlling temperature before any visit. It should be noted that the procedure performed in the field was in line with the authorizations of the public authority responsible for the COVID-19 in Paraná Coast.

Initially, the interviewees answered questions about their socioeconomic profile related to the age group, length of experience in the activity and family composition. Subsequently, they answered questions about factors such as income, commercialization and social issues.

After this phase, following the proposals of Anacleto, Scheuer, Cury and Oliveira (2020), a cross-impact matrix was organized. The authors describe the matrix as the crossing of the implications among them, and later of the opportunities. The matrix uses percentage values from 0 to 100 for each opinion expressed by the interviewees collectively in relation to the other opinions expressed, comparing each item analyzed in the relation of the influence exercised and the influence suffered in the fishing activity, as well as the higher the index, the greater the relevance and the attention to be given to the solution of the problem suffered by women shellfish collectors or the appreciation to be given to the opportunities.

The impact matrix generates an index of relevance (importance for development) that can be obtained by the equation:

$$
\mathrm{IR}=(\mathrm{FA} \times \mathrm{FB} \times 10) / \Sigma \mathrm{SF}
$$

Where:

$\mathrm{IR}=$ Relevance Index of the assessed situation;

$\mathrm{FA}=$ Index of influence suffered;

$\mathrm{FB}=$ Index of influence exercised;

$\sum \mathrm{SF}=$ Sum of the indexes (FA $x$ FB) of all the questions analyzed. 
After data collection was completed, according to what was proposed by Vergara (2015), an interpretative analysis was adopted, which was performed using the data triangulation technique with similar groupings, with the focus on classifying elements that could be perceived similar or relatively homogeneous, based on the set of questions surveyed. Thus, it was sought to homogenize the possible objects within groups and, simultaneously, maximize the heterogeneity among the investigated group.

\section{Results}

The study revealed that women are in fact predominant in the activity, with the presence of men not being recorded in this activity during the data collection in the field. The average age was 49 years old, and the time dedicated to the activity was around 33 years, which showed that women have been developing the activities related to the extraction of mollusks since adolescence.

Thus, similarly to what was described by Figueiredo and Prost (2011), in Paraná Coast the collection of shellfish is also a cultural heritage, being spread from generation to generation, initially learned in childhood and improved over the years.

The study also found that women shellfish collectors had an average of 4 children, and had a low level of education and high levels of illiteracy (Figure 2).

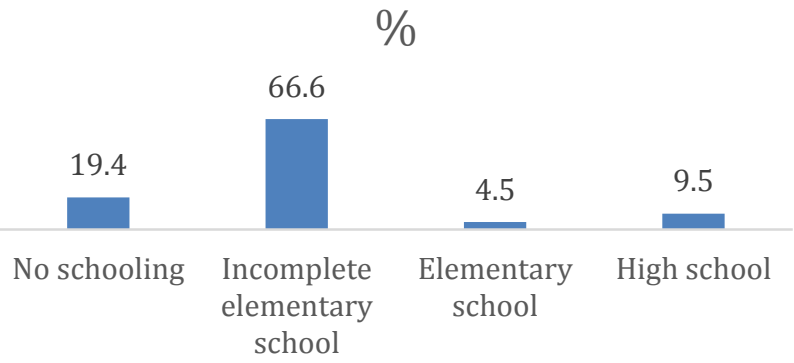

Figure 2. Percentage level of education among women shellfish collectors in the State of Paraná - Brazil)

The activity in Paraná Coast comes in two forms, with all respondents working in both modalities. The first is the tacit contract by fishmongers and other establishments. In this case, the entrepreneur, the seafood collectors and women shellfish collectors work on a daily basis, receiving payment per kilogram of clean production or even a day of service.

The second modality is when the family promotes the collection of the shellfishes in the sea. In this case, upon arrival at their homes, the women promote pre-cleaning, washing in fresh water, boiling the mollusks, cooling, packaging the production, discarding the shells, cleaning the workplace and finally they sell the products.

The average income obtained in the activity was around USD 107.90, with the majority of the interviewees $(\mathrm{n}=$ 93\%) having in the activity the only source of income. It is noteworthy that in view of the income obtained, these women can be classified in the group of people living on the "poverty line", which are the people who receive an income of up to US\$ 5.5 (approximately R $\$ 22.00$ ) per day, adopted by the World Bank (2003) to identify poverty in developing countries.

The low income promotes that the women who develop this activity look for other work alternatives, such as daily cleaning service or something in the local commerce, as a form of income supplement. It should be noted that during the COVID-19 pandemic, most of the interviewees $(n=91 \%)$ had access to government emergency aid, financial support from the Federal Government for the population whose work was impaired.

The trade system adopted by them preferably is direct sales to consumers, common in the door-to-door sales system. However, sales systems for middlemen and market owners have also been recorded.

The shellfish residues are disposed of in several ways, such as: use as a landfill $(n=47 \%)$, use as fertilizer $(n=33 \%)$ and disposal in the mangrove $(\mathrm{n}=5 \%)$.

The health of these women is a factor that deserves careful analysis in the context of the activity, given that $86 \%$ of 
the interviewees reported that due to the unhealthiness they are subjected to excessive humidity and the repetitive movements, they have already had some health problem derived from the work activity. Among the health problems most reported by the interviewees, backpain, due to long standing, and bladder pain due to being exposed to humidity for a long time $(\mathrm{n}=57 \%)$. Other factors that put health at risk were also reported, accidents at work $(\mathrm{n}=$ $28 \%$ ) and colds that affect all women in the activity, and the probable explanation for this high rate of diseases in the workplace may lie in the fact that $66 \%$ of the interviewees affirmed that they did not use any type of personal protective equipment. Being considered as essential equipment in the practice of the activity, the use of gloves, moisture insulating boots, long-sleeved blouse and raincoat.

The study on women shellfish collectors revealed that the main implications were associated with the low income received by the activity and the unhealthy environment, and the potentialities, such as generating income for impoverished communities and reconciling professional activities with domestic activities, were the more highlighted (Table 1).

Table 1. Diagnosis related to the activities of women shellfish collectors in Paraná Coast

\begin{tabular}{|c|c|c|c|c|c|}
\hline & Threats (implications) & IR & & Opportunities (strengths) & IR \\
\hline 1 & Low income from the activity & 32,2 & 1 & $\begin{array}{l}\text { Income generation for impoverished } \\
\text { communities }\end{array}$ & $\begin{array}{l}26,1 \\
2\end{array}$ \\
\hline 2 & Unhealthy environment & 20,3 & 2 & $\begin{array}{l}\text { Reconciliation of professional activities } \\
\text { with domestic ones }\end{array}$ & $\begin{array}{l}20,8 \\
2\end{array}$ \\
\hline 3 & Lack of class organization & 16,1 & 3 & Proximity to large consumer centers & 9,88 \\
\hline 4 & $\begin{array}{l}\text { Strong competition among women } \\
\text { shellfish collectors in } \\
\text { commercialization of production }\end{array}$ & 7,7 & 4 & Summertime facilitates the trade & 9,88 \\
\hline 5 & Low price paid by middlemen & 6,02 & 5 & $\begin{array}{l}\text { Regional conditions favorable to the } \\
\text { activity development }\end{array}$ & 7,14 \\
\hline 6 & Lack of adequate materials for collection & 6,02 & 6 & Demand for the product & 6,19 \\
\hline 7 & Perishable product & 4,91 & 7 & $\begin{array}{l}\text { Product related to the traditional regional } \\
\text { cuisine }\end{array}$ & 6,19 \\
\hline 8 & $\begin{array}{l}\text { Lack of transport in order to sell the } \\
\text { production. }\end{array}$ & 3,57 & 8 & $\begin{array}{l}\text { Large areas available for growing } \\
\text { mussels }\end{array}$ & 5,01 \\
\hline 9 & $\begin{array}{l}\text { Difficulty in accessing production } \\
\text { buyers. }\end{array}$ & 2,19 & 9 & $\begin{array}{l}\text { Production activity is consolidating in } \\
\text { the region, expanding the sustainable } \\
\text { development and reducing extraction }\end{array}$ & 4,78 \\
\hline 10 & Few alternatives to regional income & 1,08 & 10 & $\begin{array}{l}\text { Possibility to migrate from extractivism } \\
\text { to cultivation }\end{array}$ & 3,99 \\
\hline
\end{tabular}

\section{Discussion}

The difficulties imposed by this activity affect most women, given that a significant portion of the interviewees $(60 \%)$ did not consider shellfish collection to be a pleasant activity and reported not having total satisfaction in the profession. This high level of dissatisfaction in the profession may be linked, in addition to the unhealthy conditions (excessive humidity) to which they are subjected during the period of work, but also the remuneration considered low. However, the conditions experienced by these women have apparently prevented them from promoting migration to other, more profitable professional activities.

Low education linked to other factors (age and family background) may be influencing the interviewees' relationship with the job market and acting as a limiting factor in the search for new professional opportunities. According to Anacleto, Coelho and Curvelo (2016), invariably, people over the age of 30 years old and associated with low levels of education have greater difficulties in finding vacancies in the formal job market with good pay, and in Brazil, segregation makes this endeavor even more difficult for women. Thus, these women obtain their wages informally and, in the reality of the interviewees, it turns out that shellfish collection is an important alternative to have a job 
and income for these women, in addition to being a possible type of livelihood, which also allows women to work close to their homes and also be able to take care of their children.

Similar studies developed by Anacleto et al. (2016) in Paraná Coast, reveal that the number of women in a single parent family or as the main provider of the home is $37.3 \%$, a factor that may also be limiting the search for new alternatives in the market, given that, according to Anacleto, Soares and Femenias (2021), despite the Brazilian woman, with much effort, left the private space of the house, and despite assuming this new activity, the study showed that related to Paraná Coast, similarly to other regions of Brazil and the world, the achievements obtained did not exempt them from their old duties, and it imposed on women the expansion of activities, creating an overload of functions for women who live in Paraná Coast, which in many cases, in addition to domestic issues, fulfill the role of mother, assist in studies and still need to support psychologically and socially their children, in addition to generating income.

Thus, in the small communities in Paraná Coast, where there is a lack of alternatives, this activity spread from generation to generation may have its origin in the absence of alternatives by the women involved in it than in fact by the historical question and identification with the activity. Anacleto et al. (2021), affirm that an effective autonomy of women depends on the recognition that their well-being is directly influenced by their economic independence, which also reflects in their social emancipation. In this context, although it seems obvious, the search for better paid activities apparently becomes a relevant path for them in Paraná Coast. Artisanal fishing in Brazil has always been an economic practice in Brazilian territory, specifically in the State of Paraná.

From the 1970s, with the development of new technologies, such as large vessels and the location of shoals via GPS, there was an overwhelming gap between the species' natural capacity for regeneration and the stock of fish and shrimp removed from the coast. This fact caused a decline in the quantity of fish caught and increased production costs due to a greater effort in the catch. Specifically, in Paraná Coast, the decline in fishing was more accentuated in the traditional communities of remaining fishermen "Caiçara origin", who started to have economic difficulties, and abandoned the fishing activity. However, hundreds of families in the struggle for survival, began the search for alternatives to survive through the collection of other types of marine animals, including mussels or shellfishes.

Thus, as Castello (2007) reports, the biological production of resources is conditioned by a complex of biotic and abiotic factors that are beyond human control, with the exception of the fishing effort. Still according to the same author, the extraction of these marine animals is economic activities and are, therefore, very sensitive to the market demands. Considering that the consumer market for fishery products grows continuously, prices rise, stimulating the increase of efforts and greater exploitation, which, in a perverse cycle, usually feeds the process back to the overexploitation and the scarcity of this resource.

Finally, the debate on the development of a regional activity must originate in the interaction and dialogue among the actors involved in the extraction of the shellfish, the dialogic must accept the contradictions of the reality, including its antagonisms and its contradictions. It is accepted different levels of reality, where different logics can operate, and the transformations generated by the actors reflect on a new reality that imposes that the previous reality succumbs, but it can bring with new contradictions and new limitations in an endless flow where development is modified and for its consequence it modifies the region. In this context, it is urgent that the improvement of the quality of life of these women is anchored in several factors, but, especially, that the agents that will bring this change, in addition to technical, academic or empirical training, are also humanistic and create a favorable environment for the generation of solutions for a new model of development and exploitation of the activity, which even in the face of so many reported challenges, seeks to reduce social asymmetries, preserve the environment and generate income and develop to the regional economy in a balanced and sustainable manner.

Even nowadays, the activity is performed most of the time in improvised places and close to their homes. The highest levels of commercialization occur in the period of seasonal tourism in the summer time, which is between November to March, however, the most distant communities do not benefit from this important commercial niche.

The shellfish of this species offered to tourists or in public markets, fishmongers and restaurants are almost entirely of extractive origin, however overexploitation is viewed with fear. According to Anacleto et al. (2010), the vast majority of extractors believe that the availability of mussels in natural environments has been drastically reduced in the last decade and point out that the introduction of crops, although costly, requires simple technology, is sustainable and economically viable, and that it would be a relevant alternative to regional development, in addition to providing an opportunity to improve the quality of life of people in social vulnerability, such as women shellfish collectors. The introduction of new crops would greatly reduce extraction in Paraná Coast, and it would give longevity to the activity made by women. According to Lins (2006), it is necessary to highlight the sharing of views 
and conduct on problems and opportunities and also to highlight the aspects inherent to the actors in collective action and the regional vocation, pointing out the potential to carry out innovation that may meet the wishes of a community or region.

However, the implantation of this cultivation by women is apparently far from being a possibility, given that the class presents itself on a disorganized scale. This statement is based on the fact that was not found any kind of association, cooperative or informal representation groups of this class in the region. The only formal entity is the Fishermen Colony (Colônia de Pescadores), whose main objective is to defend the interests of artisanal fishers of fishes and shrimps. Another aggravating factor observed is that there are no incentives on the part of the public authorities for the implantation of this kind of crops, as well as there are no lines of financing for this culture available from banking institutions that traditionally finance agribusiness. Even more serious, there is a shortage of technicians in the region in quantity to serve families that need orientation to guide extraction and trade the products.

Examples the situation that transformed extractors into producers occur in several Brazilian regions, according to Lins (2006), the process of developing crops in the State of Santa Catarina involved interaction between producers and researchers, such interactions that evoke the importance of university extension simultaneously to research, were fundamental because, by nurturing scientific research associated with the technological issue, they contributed to the improvement of the cultivation practices and aroused the interest of other people in the communities, including the discovery of low-cost facilities, such as the case of bamboo, similar to the situation described in Santa Catarina, in Paraná Coast, this low-cost facilities could be an alternative for inserting poor families into the activity, thus transforming extractors into producers and reducing impacts on the natural population of mussels. According to Igarashi (2008), the success shown in Santa Catarina can be extended to other areas of Brazil, including the southern coast of Paraná State, where the water conditions are ideal for cultivation practices.

The activity has a high rate of waste generation, although the interviewees have the perception that waste is not a problem, and currently this waste is being deposited in inappropriate places, such as burial at the backyards, which can generate the saturation of this element also known as antagonism of chemical elements in the soil, or the deposit in the mangroves, which can generate the proliferation of pests. There is an urgent need to rethink the fate of this material, since the raw material has recognized value and could be sold to industries and feed factories. Under this focus, Moraes (2005) describes the associativism as an organizational model capable of effectively solving problems related the sector, in addition to encouraging the participation of the State in the promotion and organization of the system, that is, it may have an important role in the formation and support of these families, especially in resolving the impasse generated by the waste.

The reuse practice has been widely used and widespread throughout the world where raw materials have strategic aspects, aiming at using waste as a differential, applying it to green marketing, advertising and benefits offered by governments to the industries. It is inferred shells can be used as calcium flour in food supplementation for children, adults, elderly, lactating and pregnant women (Lerner, Lei, Chaves \& Freire, 2000), and can be an important solution in cases where people have lactose intolerance. This product has a great absorption power in the human organism (70\%), an index much higher than the other calcium carbonates, which effect only reaches $10 \%$. Perna perna mussel that is widely consumed in Paraná (Anacleto et al., 2010), showed calcium levels very similar to those found for oysters (Finkelstein, Wohlt, Emanuele \& Tweed, 1993) being considered a product capable of supplying about $65 \%$ of calcium, to animals (Stori, Bonilha \& Pessati, 2003).

The shellfish residues, in addition to the aforementioned utilities, are fully utilized in other activities, such as what already occurs in Santa Catarina, where the residues are transformed into materials for civil construction, soil correction and fertilizers, and finally as reported by Anacleto et al. (2010), artisans from other regions commonly travel to these communities in an attempt to collect the shells to use in handicrafts. Thus, the residues currently in the described regions can be understood as potentialities underused by these shellfish collectors.

In this context, there is an urgent need to propose strategic actions planned in the segment that can result in investments and actions that are related to the concept of sustainable development, and make it possible to improve the quality of life of these people.

However, the women shellfish collectors from Paraná Coast have not yet established levels of organization that could enhance the bargaining power with institutions and that could result in a viable alternative for the general improvement of the activity, especially related to the possibility of creating less asymmetrical relations in commercial question. According to Anacleto (2018), historically in the fish production chain, the fisherman has the minimum part, receiving the equivalent of only $2.7 \%$ of net profits obtained in the entire production chain. 
Thus, the low capacity for collective organization promotes that they are not able to make themselves heard by people and institutions which could address solutions to mitigate the problems and break the conditions of poverty that they are currently submitted and, because the organization does not occur, the ability to strengthening their social conditions continues to weaken, which explains the invisibility of these communities with the government, since that women are the main responsible for the supply of shellfish in Paraná Coast. Even so, there are many gaps that prevent families that live in these impoverished communities can use these natural resources for their benefit, continuing to live in socially vulnerable conditions.

The context linked to shellfish collection and production show some situations, such as the lack of public policies for sustainable extraction, the difficulty of accessing forms of credit for this cultivation and even the orientation for the implantation of crops at the sea, and all of these prevented these people from accessing satisfactory sources of income for their food guarantee and survival, resulting in professionals living in slums, without worthy conditions of survival.

The collective organization can be considered the main alternative for this group of women in order to fight for better conditions of remuneration, work environment and quality of life. Thus, it is necessary to debate alternatives and that the communities have greater organizational capacity, in the sense that alternatives for cultivation to generate family income are made viable. Therefore, taking advantage of the fact that communities have historical knowledge about this mollusk, this historical vocation linked to the availability of technical and management knowledge with the essential support of public policies that suit these communities, may result that, in addition to improving the quality of life, the preservation of knowledge and local biodiversity occurs, avoiding that traditional knowledge is not lost by the exodus of the activity.

Apparently, this group of women alone will not be able to solve their own problems in a short period of time, and the main way to improve the situation may lie in the dialogue on the knowledge and tradition, involving science by universities, public authorities and the shellfish collectors in the communities, which must be heard in order to seek concrete alternatives to mitigate the problems observed. The reorientation of these women with an eye on themselves, involving economics, politics and self-management, could transform the individualistic reality into a reality that is communally supported by collective actions, providing a more comprehensive and knowledgeable view of local needs, considering the needs of these women and that can, over time, guide the fairer and more symmetrical vision of the future.

Finally, it is possible that the collective organization of these shellfish collectors can in fact reverse the long-term cycle of difficulties historically installed, where these women are impoverished and are unable to access resources to improve production, processing and trade, and, as they do not have access to funding resources to improve production, they remain impoverished.

Thus, the interlocution among the actors is an essential condition in the construction of new approaches that aim to improve the life of this group of women, in a sustainable way, since it can point out the needs of adjustments, logistical corrections and technological changes that can generate the privileged information on consumer desires, autonomy in the process of collecting, producing and reducing dependence on other commercial spheres, resulting in the strengthening and permanence of these women in their traditional communities.

\section{Conclusion}

The study revealed that women are predominant in the activity, with no presence of men. The average age was 49 years old, and the time devoted to work in the activity was around 33 years, which shows that women have been developing the activity related to the extraction of mollusks since adolescence.

The study also pointed out that women shellfish collectors had an average of 4 children, and had a low level of education and high levels of illiteracy.

The average income obtained in the activity was on average USD 107.90, with the majority of the interviewees $(\mathrm{n}=$ 93\%) having in this activity the only source of income. It should be noted that in relation to the income obtained, these women could be classified in the group of people living on the "poverty line", who are the people who receive an income of up to US $\$ 5.5$ (approximately R $\$ 22.00$ ) per day.

The health of these women is a factor that deserves careful analysis in the context of the activity, since $86 \%$ of the interviewees reported that in the face of unhealthiness they are subjected to excessive humidity and repetitive movements, they have already had some health problem derived from the activity. 
The main implications of the activity were associated to low income and unhealthy environment, and the potentials, such as income generation and the possibility of reconciling professional activities with domestic activities, were the most positively highlighted.

Therefore, it is finally possible to consider that the collective organization of women shellfish collectors can in fact reverse the historically installed cycle of difficulties in the long term, where these women are impoverished and are unable to access the resources in order to promote production, processing and trade of the products, and, because they do not have access to funding resources to improve production, they remain impoverished.

\section{References}

Alexandrino, A. S., \& Silva, A. A. D. (2015). Pilares da tradição: o conceito de tradição no estudo da História das instituições. Revista do Lhiste-Laboratório de Ensino de História e Educação, 2(3). Retrieved from https://seer.ufrgs.br/revistadolhiste/article/view/59708/0

Anacleto, A. (2018). Cadeia produtiva da pesca de siri com gaiolas no litoral paranaense: características, implicações sociais, ecológicas e perspectivas econômicas. In M. T. Sulzbach, D. R. Archanjo, \& J. Quadros (Eds.), Litoral do Paraná: território e perspectivas (Vol. 3, pp. 178-207). Rio de Janeiro, RJ: Autografia.

Anacleto, A., Coelho, A. P., \& Curvelo, E. B. C. (2016). As mulheres empreendedoras e as feiras livres no litoral do paraná. Revista Faz Ciência, 18(27), 118. Retrieved from http://saber.unioeste.br/index.php/fazciencia/article/view/12778

Anacleto, A., Cordeiro, S. A., Mattos, P. R., \& Elero, M. D. (2010). A mitilicultura no litoral Paranaense: desafios e $\begin{array}{lllll}\text { oportunidades. Revista } & \text { TechnoEng, } & 2 . & \text { Retrieved } & \text { from }\end{array}$ http://www.cescage.com.br/revistas/index.php/RTE/article/view/761

Anacleto, A., Scheuer, L., Cury, A. C., \& Oliveira, L. R. A. (2020). Flowers retail trade market: an application of Porter's Strategic Taxonomy. Ornamental Horticulture, 26(2), 236-243. Retrieved July 15, 2020, from https://doi.org/10.1590/2447-536x.v26i2.2154

Anacleto, A., Soares, F. C., \& Femenias, N. F. (2021). Superendividamento e crise econômica do novo coronavírus: impactos nas mulheres do litoral do Paraná. Princípios 1(16), 2675-6609. https://doi.org/10.4322/principios.2675-6609.2020.160.009

Andreoli, V. M., \& Anacleto, A. (2006). Compartilhando saberes: os conhecimentos tradicionais e a educação ambiental. Encontro Paranaense de Educação Ambiental-EPEA, IX. Retrieved from http://www.iseperondon.com.br/inc/pdf/isepe_guaratuba_artigo007.pdf

Aragão, M. C. O., \& Melo, R. (2011). O Cotidiano Da Pesca Artesanal Na Ilha Mem De Sá-Itaporanga D 'Ajuda-Litoral Sul De Sergipe. Seminários Espaços Costeiros, 1. Retrieved from https://cienciasmedicasbiologicas.ufba.br/index.php/secosteiros/article/viewFile/14667/10022

Bourdieu, P., Curto, D. R., Domingos, N., \& Jerónimo, M. B. (1989). O poder simbólico.

Cardoso, E. S. (2005). Trajetórias: a formação de pescadores e a apropriação da natureza. Simpósio Nacional sobre Geografia, Percepção e Cognição do Meio Ambiente. Londrina, PR. Retrieved from https://geografiahumanista.files.wordpress.com/2009/11/eduardo_s_cardoso.pdf

Castello, J. P. (2007). Gestão sustentável dos recursos pesqueiros, isto é realmente possível. Pan-American Journal of Aquatic Sciences, 2(1), 47-52.

Coutinho, E. G. (2005). Os sentidos da tradição. XXV Congresso Brasileiro de Ciências da Comunicação - Salvador, $B A$. Retrieved from http://www.portcom.intercom.org.br/pdfs/121978947430223113883825169264384783123.pdf

Diegues, A. C. S. (1983). Pescadores, camponeses e trabalhadores do mar. São Paulo, SP: Ática.

Falcão, I. R., Couto, M. C. B. M., Lima, V. M. C., Pena, P. G. L., Andrade, L. L., Müller, J. S., ... Rêgo, R. C. F. (2015). Prevalência dos distúrbios musculoesqueléticos nos membros superiores e pescoço em pescadoras artesanais/marisqueiras em saubara, Bahia, Brasil. Ciência \& Saúde Coletiva, 20(8), 2469-2480. https://doi.org/10.1590/1413-81232015208.17272014

Fernandes, R. D. C. P., Lima, M. A. G. D., \& Araújo, T. M. D. (2014). Tópicos em saúde, ambiente e trabalho: um olhar ampliado. Retrieved from http://repositorio.ufba.br/ri/handle/ri/15083 
Figueiredo, M. M., \& Prost, C. (2011). A mariscagem e as mulheres na Baía do Iguape-BA. I Seminário espaços costeiros. Retrieved from https://periodicos.ufba.br/index.php/secosteiros/article/view/14669

Finkelstein, A. D., Wohlt, J. E., Emanuele, S. M., \& Tweed, S. M. (1993). Composition and nutritive value of ground sea clam shells as calcium supplements for lactating Holstein cows. Journal of Dairy Science, 76(2), 582-589. https://doi.org/10.3168/jds.S0022-0302(93)77378-6

Igarashi, M. (2008). Potencial econômico da mitilicultura no Brasil. UNIMAR, 13. Retrieved from https://www.unimar.br/biblioteca/publicacoes/2009/unimar_ciencias17.pdf\#page=13

Lerner, B. R., Lei, D. L. M., Chaves, S. P., \& Freire, R. D. (2000). O cálcio consumido por adolescentes de escolas públicas de Osasco, São Paulo. Revista de Nutrição, 13(1), 57-63. https://doi.org/10.1590/S1415-52732000000100008

Lins, H. N. (2006). Sistemas agroalimentares localizados: possível" chave de leitura" sobre a maricultura em Santa Catarina. Revista de Economia e Sociologia Rural, $44(2), \quad 313-330$. https://doi.org/10.1590/S0103-20032006000200008

Little, P. E. (2006). Ecologia política como etnografia: um guia teórico e metodológico. Horizontes Antropológicos, 12(25), 85-103. https://doi.org/10.1590/S0104-71832006000100005

Mafra, J. S. (1952). História de Guaratuba. Guaratuba, PR: Prefeitura Municipal.

Ministério da Saúde. (2018). Cartilha: A saúde das pescadoras artesanais | atividades de pesca: rios, lagos e lagoas. Brasília, DF: Ministério da Saúde. Retrieved from http://bvsms.saude.gov.br/bvs/publicacoes/saude_pescadoras_artesanais.pdf

Monteiro, I. R. T. (2014). Modelagem etnoecológica do território da pesca artesanal em Ilha de Maré, Salvador-BA. Dissertação de mestrado, Universidade Estadual de Feira de Santana, Feira de Santana, BA, Brasil. Retrieved from https://s3.amazonaws.com/ppgm.uefs.br/Disserta\%C3\%A7\%C3\%A3o_final_Igor.pdf

Moraes, L. E. D. O. (2005). A cooperação na cadeia produtiva da maricultura do Estado de São Paulo. Tese de doutorado. Escola Politécnica da Universidade de São Paulo, São Paulo, SP, Brasil. Retrieved from https://www.equatorinitiative.org/old/images/stories/2002winners/Coop_Ostras/cooperacao_cadeia.pdf

Mundial, B. (2003). Globalização, crescimento e pobreza. São Paulo, SP: Futura.

Oliveira, B. M. C., Araújo, G. V. R., Steuer, I. R. W., \& El-Deir, S. G. (2012). Percepção ambiental dos pescadores de marisco do litoral norte de Pernambuco. II Congresso Brasileiro de Gestão Ambiental Goiânia, GO. Retrieved from http://www.ibeas.org.br/congresso/Trabalhos2012/XI-043.pdf

Pena, P. G. L., Freitas, M. D. C. S. D., \& Cardim, A. (2011). Trabalho artesanal, cadências infernais e lesões por esforços repetitivos: estudo de caso em uma comunidade de mariscadeiras na Ilha de Maré, Bahia. Ciência \& Saúde Coletiva, 16(8), 3383-3392. https://doi.org/10.1590/S1413-81232011000900005

Santos, L. X. C. (2019). Condicionantes socioambientais de saúde de marisqueiras da Ilha de Mem de Sá, Itaporanga D'Ajuda-SE. Retrieved from https://ri.ufs.br/jspui/handle/riufs/12750

Simon, M., \& Silva, F. C. (2006). Custo de produção da ostra nativa no município de Guaratuba-Pr. Florianópolis, SC: Fixarte.

Souza, R. R. S., \& Silveira, M. A. T. (2016). Interpretação patrimonial e turismo em centro histórico: uma proposta para o munícipio de Antonina, Paraná, Brasil. Geografia e Pesquisa, 9(2). Retrieved from http://vampira.ourinhos.unesp.br/openjournalsystem/index.php/geografiaepesquisa/article/view/236

Stori, F. T., Bonilha, L. E. C., \& Pessati, M. (2003). Inventario da geração de resíduos de pescados em Santa Catarina, Anais: I Workshop brasileiro de aproveitamento de subprodutos de pescados. Itajaí. Anais, UNIVALE. CD-ROOM.

Vergara, S. (2015). Metodologia de pesquisa. Rio de Janeiro, RJ: Atlas.

\section{Copyrights}

Copyright for this article is retained by the author(s), with first publication rights granted to the journal.

This is an open-access article distributed under the terms and conditions of the Creative Commons Attribution license (http://creativecommons.org/licenses/by/4.0/). 